Saudi Journal of Humanities and Social Sciences

Abbreviated Key Title: Saudi J Humanities Soc Sci

ISSN 2415-6256 (Print) | ISSN 2415-6248 (Online)

Scholars Middle East Publishers, Dubai, United Arab Emirates

Journal homepage: https://saudijournals.com

Original Research Article

\title{
Ambivalent Sexism towards Women and Acceptance of Rape Myths among University Students
}

\author{
Sana Nisar ${ }^{* *}$, Komal Zafar ${ }^{1}$, Dr. Iram Batool ${ }^{1}$, Mehwish Ishfaq ${ }^{1}$, Hira Fatima ${ }^{1}$, Kanwal Fatima ${ }^{1}$ and Rida Arshad ${ }^{1}$ \\ ${ }^{1}$ Bahauddin Zakariya University, Multan, Pakistan
}

DOI: $\underline{10.36348 / \mathrm{sjhss} .2021 . v 06 \mathrm{i} 02.007}$

| Received: 29.01.2021 | Accepted: 16.02.2021 | Published: 27.02.2021

*Corresponding author: Sana Nisar

\section{Abstract}

Victims of rape sometimes suffer from being blamed for their assault. The present study aimed to investigate whether hostile sexism, benevolent sexism influence acceptance of rape myths. The sample comprised of 240 university students recruited from Bahauddin Zakariya University, Multan. Demographic information sheet, Illinois Rape Myth Acceptance Scale (IRMA) [24], Ambivalent Sexism Inventory (ASI) [13] and scales were used for assessment. Results from Bivariate Correlation analysis showed that, Hostile sexism and subscales of benevolent sexist beliefs are positively correlated with rape myths. Subscales of Ambivalent Sexism (Hostile sexism, Paternalism, Heterosexuality and Gender differentiation) positively predicted subscales of Rape myths acceptance (she asked for it, it wasn't really rape, he didn't mean to and she lied). Results further showed that males had higher acceptance with Rape Myths and Ambivalent Sexism. Findings from the present study suggest that there is need to tackle negative stereotypes about rape victims and Interventions should focus more on the education on what rape and sexual assault are and what the health and legal consequences entail.

Keywords: Ambivalent Sexism Rape Myths University Students.

Copyright (C) 2021 The Author(s): This is an open-access article distributed under the terms of the Creative Commons Attribution 4.0 International License (CC BY-NC 4.0) which permits unrestricted use, distribution, and reproduction in any medium for non-commercial use provided the original author and source are credited.

\section{INTRODUCTION}

Rape is serious crime that frequently occurs all over the world. For example, According to Human Rights Commission of Pakistan, there are 320 completed rapes and 350 gang rapes were reported in Pakistan in 2004 [1]. Around the world, it is estimated that approximately 85,000 women are victims of rape, and more than 400,000 are victims of harassment every year $[2,3]$. The prevalence of this crime is particularly higher adults and students, with out of four women in US [4], and one out of seven women experience sexual assault during their university period in the UK [5]. There is need to focus on rape, because it has not only severe short and long-term psychological, social and economic effects on the victims, but as a sexual stigma it also it is one of the crime in which the victims are victimized by society.

There are many misperceptions about rape and rape victims due to violent, sexual, and personal nature of rape. These misperceptions can be defined as rape myths, these widely held myths are generally negative and stereotypical beliefs about assault, victims and perpetrators $[6,7]$. These false beliefs play an important role in defending male sexual aggression against women and rape victims. Rape myths are held by many individuals within society and indicate that victims are lying, imply a rape did not occur, or that the rapist was motivated [8]. Some beliefs suggest that the perpetrator was unable to control sexual desires or victim deserved to be raped due to their behavior, appearance and dressing [9-11].

Several factors influence rape myth such as stereotypical attitude toward women [12]. One construct is ambivalent sexism that describes ambivalent prejudice against women [13]. The two dimensions of sexism are hostile and benevolent sexism. Hostile sexism is antipathy and hostility towards women who are authoritative, women who are independent, and women who disrespect the honor of men. On the other hand, benevolent sexist attitude reflects negative reaction towards women who do not perform their conventional roles [14, 13].

Several studies have investigated the relationship between sexism and beliefs about victims of sexual abuse and violence, men's inclination to rape [15], justifying the behaviors of perpetrators and 
blaming the victims [16, 17], rationalization of sexual violence against married women violence [18], and beliefs about domestic violence and blaming the victim [19]. Number studies have also found Gender differences in traditional attitudes toward women, sexism and false rape beliefs [20-22]. There is limited information about the relationship between these constructs among university student sample in Pakistan.

Research showed that the beliefs of individuals who engage in sexual behavior, such as rape are different from those who avoid such behaviors. There are some factors such as victim blaming, sex role attitudes and relationship skills contribute to an individual's rape supportive attitudes [23]. The purpose of this research is to examine sexist attitudes and rape myths among University students and how they are contributing in the prevalence of rape in Pakistan.

\section{METHOD}

A quantitative study with correlation research design was conducted on students to identify effects of ambivalent sexism on rape myth acceptance.

\section{Sample}

Data was collected from 240 university students recruited from Bahauddin Zakariya University, Multan, Pakistan. The average age of the participants was 21 years. Both males $(\mathrm{n}=188)$ and females $(\mathrm{n}$ $=122$ ) were included in the sample. The average monthly family income of the participants was 68,000. Majority of the participants were recruited from Bachelors and Master Programs accounting for 58\% and $29 \%$ of the sample. Of the participants $62 \%$ were belonged to urban areas and $37 \%$ were from rural areas living in hostels and most of the participants reported Nuclear family system.

Table-1: Socio Demographic Characteristics of the Patients ( $=147)$

\begin{tabular}{|l|l|l|l|}
\hline Variables & f \% & M & SD \\
\hline Age & & 21.21 & 14.09 \\
\hline Monthly Family Income (PKR) & & 68133.33 & 53211.10 \\
\hline Gender & & & \\
\hline Men & $118(49.2)$ & & \\
\hline Women & $122(50.8)$ & & \\
\hline Education & & & \\
\hline BS (hons.) & $140(58.3)$ & & \\
\hline Masters & $70(29.2)$ & & \\
\hline M.phill & $30(12.5)$ & & \\
\hline Family background & & & \\
\hline Rural & $91(37.9)$ & & \\
\hline Urban & $149(62.1)$ & & \\
\hline Family system & & & \\
\hline Nuclear & $138(57.5)$ & & \\
\hline Joint & $102(42.5)$ & & \\
\hline
\end{tabular}

\section{Assessment Measures}

Illinois Rape Myth Acceptance Scale. To assess rape myths Illinois Rape Myth Acceptance Scale, Short Form (IRMA-SF) was used developed by Payne et al. [24]. The scale consists of 22 items with 5-point Likert scale, ranging from strongly agree to strongly disagree, high scores indicate more rejection of rape myths. The 4 subscales of the instrument investigate attitude towards female rape victim, such as "she asked for it", "it wasn't really rape", "He didn't mean to" and "she lied". The cronbach alpha of present study was .81 .

Ambivalent Sexism Inventory (ASI) Glick and Fiske's [13]. To measure two types of sexist attitude toward women; hostile sexism and benevolent sexism Ambivalent sexism Inventory was used. The scale consists of 35 items with 5-point Likert scale, ranging from strongly agree to strongly disagree. Higher scores indicate more sexist attitudes. The scale has total number of four subscales Hostile sexism and benevolent sexism has three subscales such as Protective Paternalism (women should be protected by men because they are weaker), Gender Differentiation (women are unable to govern social institutions) and Heterosexual Intimacy (women sexually attract men to have dominance over men). The coefficient alpha of the scale was. 85 .

\section{RESULTS}

Results were calculated through IBM SPSS Statistics 21. Bivariate correlation analysis was conducted to identify relationship among all variables. Results showed that Protective paternalism, heterosexual intimacy, gender differentiation and hostile sexism are positively correlated with subscales of rape myth acceptance (she asked for it, it wasn't a rape, he didn't mean to, she lied). (Table 2) 
Table-2: Bivariate Correlation analysis between subscales of ambivalent sexism and rape myth acceptance $(\mathrm{N}=\mathbf{2 4 0})$

\begin{tabular}{|l|l|l|l|l|l|l|l|l|}
\hline Sr\# & Variables & $\mathbf{2}$ & $\mathbf{3}$ & $\mathbf{4}$ & $\mathbf{5}$ & $\mathbf{6}$ & $\mathbf{7}$ & $\mathbf{8}$ \\
\hline 1 & Protective Paternalism & $.64^{* *}$ & $.74^{* *}$ & $.64^{* *}$ & $.57^{* *}$ & $.56^{* *}$ & $.63^{* *}$ & $.60^{* *}$ \\
\hline 2 & Heterosexual Intimacy & - & $.64^{* *}$ & $.59^{* *}$ & $.56^{* *}$ & $.62^{* *}$ & $.58^{* *}$ & $.52^{* *}$ \\
\hline 3 & Gender differentiation & - & - & $.74^{* *}$ & $.69^{* *}$ & $.59^{* *}$ & $.73^{* *}$ & $.59^{* *}$ \\
\hline 4 & Hostile sexism & - & - & - & $.60^{* *}$ & $.56^{* *}$ & $.60^{* *}$ & $.58^{* *}$ \\
\hline 5 & She asked for it & - & - & - & - & $.62^{* *}$ & $.59^{* *}$ & $.51^{* *}$ \\
\hline 6 & It wasn't a rape & - & - & - & - & - & $.54^{* *}$ & $.46^{* *}$ \\
\hline 7 & He didn't mean to & - & - & & - & - & - & $.56^{* *}$ \\
\hline 8 & She lied & - & - & - & - & - & - & - \\
\hline
\end{tabular}

\section{Multiple Regressions analysis}

Four regression analyses were conducted to find of predictors of rape myths. In first analysis rape myth ("She asked for it") was regressed on subscales of benevolent sexism and hostile sexism. Model explained $59 \%$ variance in rape myth, with heterosexual intimacy, gender differentiation and hostile sexism positively predicted the myth "she asked for it". In the second regression analysis, model explained $61 \%$ variance in rape myth, with heterosexual intimacy and gender differentiation positively predicted myth ("it wasn't really rape). In the third and fourth regression analysis, model explained $55 \%$ and $66 \%$ variance, with heterosexual intimacy and hostile sexism positively predicted myth "he didn't mean to") and protective paternalism and hostile sexism positive predicted myth ("she lied") (Table 3).

Table-3: Regression Analysis for the subscales of rape myth acceptance ( $N=240)$.

\begin{tabular}{|c|c|c|c|c|c|c|c|c|c|c|c|c|}
\hline & \multicolumn{3}{|c|}{ She asked for it } & \multicolumn{3}{|c|}{ It wasn't really rape } & \multicolumn{3}{|c|}{ He didn't mean to } & \multicolumn{3}{|c|}{ She lied } \\
\hline & $\mathrm{B}$ & SE & $\beta$ & $\mathrm{B}$ & SE & $\mathrm{B}$ & $\mathrm{B}$ & $\mathrm{SE}$ & $\mathrm{B}$ & $\mathrm{B}$ & $\mathrm{SE}$ & $\beta$ \\
\hline Constant & 4.076 & .934 & & 4.694 & .945 & & -2.203 & 1.629 & & 1.965 & 1.520 & \\
\hline $\begin{array}{l}\text { Protective } \\
\text { Paternalism }\end{array}$ & .07 & .10 & .05 & .17 & .10 & .12 & .34 & .18 & .13 & .57 & .16 & $.26 * * *$ \\
\hline $\begin{array}{l}\text { Heterosexual } \\
\text { Intimacy }\end{array}$ & .26 & .10 & $.16^{* *}$ & .53 & .10 & $.34 * * *$ & .39 & .18 & $.13^{*}$ & .30 & .17 & .12 \\
\hline $\begin{array}{l}\text { Gender } \\
\text { differentiation }\end{array}$ & .22 & .09 & $.15^{*}$ & .23 & .09 & $.17 * *$ & .18 & .16 & .07 & .49 & .15 & $.23 * * *$ \\
\hline Hostile sexism & .18 & .03 & $.43 * * *$ & .06 & .03 & .15 & .38 & .05 & $.50 * * *$ & .08 & .05 & .14 \\
\hline $\mathrm{R}^{2}$ & & & .59 & & & .61 & & & .55 & & & .66 \\
\hline$\Delta \mathrm{R}^{2}$ & & & $.31 * * *$ & & & $.47 * * *$ & & & $.37 * * *$ & & & $.44 * * *$ \\
\hline F change & & & 62.48 & & & 52.05 & & & 78.85 & & & 49.96 \\
\hline
\end{tabular}

\section{Independent Sample t test}

Independent sample t-test was conducted on subscales of ambivalent sexism and rape myth acceptance. Results showed that males had higher level of hostile and sexism and benevolent sexism and higher acceptance with rape myths (she asked for it, it wasn't really rape, he didn't mean to and she lied) as compare to females

Table-4: Comparison of ambivalent sexism and rape myth acceptance among males and females $(\mathrm{N}=240)$

\begin{tabular}{|c|c|c|c|c|c|c|c|c|}
\hline & \multicolumn{2}{|c|}{ Male (118) } & \multicolumn{2}{|c|}{ Female (122) } & \multirow{2}{*}{$\begin{array}{l}\mathbf{t} \\
(238)\end{array}$} & \multirow[t]{2}{*}{ Sig } & \multicolumn{2}{|c|}{$95 \% \mathrm{CI}$} \\
\hline Variables & $\mathrm{M}$ & SD & $\mathrm{M}$ & $\mathrm{SD}$ & & & LL & $\mathrm{UL}$ \\
\hline Protective paternalism & 11.86 & 3.91 & 10.74 & 3.61 & 2.30 & .022 & .160 & 2.076 \\
\hline Heterosexual intimacy & 12.41 & 3.40 & 11.04 & 3.10 & 3.25 & .001 & .538 & 2.193 \\
\hline Hostile sexism & 9.55 & 4.07 & 30.36 & 11.20 & 3.73 & .000 & 2.890 & 9.337 \\
\hline Gender sexism & 9.55 & 4.07 & 7.81 & 3.59 & 3.49 & .001 & .754 & 2.707 \\
\hline She asked for it & 16.50 & 5.70 & 15.29 & 5.09 & 1.72 & .086 & -.169 & 2.579 \\
\hline It wasn't really rape & 18.11 & 5.67 & 15.88 & 4.56 & 3.36 & .001 & .926 & 3.540 \\
\hline He didn't mean to & 22.65 & 11.10 & 19.32 & 8.72 & 2.58 & .010 & .788 & 5.860 \\
\hline She lied & 20.38 & 8.76 & 18.22 & 7.59 & 2.04 & .042 & .076 & 4.244 \\
\hline
\end{tabular}

\section{DISCUSSION}

The study mainly aimed to investigate the role of sexist attitude in supporting rape myths towards women among University students. Findings from the study suggest positive correlation between benevolent sexism and hostile sexism and rape myths acceptance. 
These results are consistent with previous literature that used ambivalent sexism and rape supportive beliefs [25, $14,26]$.

The study also examined which type of sexist belief is associated with particular rape myth. Findings of the study revealed that Hostile sexism and the sub factors of ambivalent sexism such as heterosexual intimacy and gender differentiation are positively associated with the rape myth "she asked for it". People who believe women are weak and incomplete without the love of men and only men are able to work outside home and women should stay at home also perceive that women make themselves venerable for rape by violating these sex roles. Heterosexual intimacy and gender differentiation were also associated with another rape myth "it was not really rape". Acceptance of this myth promote stereotype that when women do job outside home and participate in social activities they cannot claim to be victim. In examining components of benevolent sexism, previous studies found positive association of gender differentiation and hostile sexism with overall rape myths acceptance. Previous literature that investigated the relationship between ambivalent sexism and rape myth acceptance also showed positive relationship between benevolent, hostile sexism and rape myth $[27,15,23,28,17,29,25]$. However heterosexual intimacy toward women was not related to rape myths [26]. The differences of findings may be due to the measurement of rape myths because each components of benevolent sexism has unique relationship with four types of rape myths, when they are measured as unitary construct the overall relationship will be obscured.

In the present study hostile sexism strongly predicted the rape myth "he didn't mean to", this reflects that men do not intend to rape they are provoked by women to have sex with them. The same myth also supported by heterosexual intimacy this reflects men's resentment to vulnerability that they are dependent on subordinate group and link their sexual motivation to genuine desire for intimacy. Hostile sexism and protective paternalism positively predicted rape myth "she lied". This suggests men only try to protect women while, women misinterpret their intentions and always exaggerate the scenario [27, 28, 26].

Present study also showed different level of hostile and benevolent sexist beliefs and rape myths among males and females. Overall, men scored higher on subscales of both ambivalent sexism and rape myth acceptance than women. Various studies showed that men ascribe more rape myths than women [30, 14, 31, 32, 33, 34, 35, 21]. Although, other studies failed to find differences in males and females on rape myths and ambivalent sexism [36-38]. The result of present study reflect that, in our patriarchal culture men are considered to be dominant, authoritative, and aggressive, they are also are expected to be the protector and provider while women are considered to be submissive, and reluctant. There are some limitations of the study such as sample of the study is restricted to the students and adults. There is need to use more representative sample across developmental lifespan. Although, sexual violence is more prevalent in women [39], Ambivalence toward men and attitude toward men who also experience assault and violence were ignored in this study. Future investigation should evaluate this topic from perspective of both males and females as rape myths works differently across genders. For future research and practice there is need to explore a wider range of variables and use of qualitative research to better understand traditional gender roles and how people perceive aspects of rape, how rape myths worked and victims are blamed, traditional gender roles. Such data may help in construction of culturally appropriate rape myths and sexist beliefs questionnaires.

Findings from the study suggest that people who misinterpret traditional gender roles are more likely to adhere with rape myths and have negative views about victims of rape and rapist. It is suggested that, there should be educational and rape prevention programs that can eliminate negative attitude and beliefs about rape victims, gender roles and sexuality. There is need to train professionals to deal more sensitively with victims to overcome worst psychological outcomes and ensure positive recovery.

\section{REFERENCES}

1. BBC News (2005). New Pakistan rape suspects held. Retrieved from http://news.bbc.co.uk/2/hi/south_asia/4656245.stm

2. Ministry of Justice, Home Office \& the Office for National Statistics. (2013). An overview of sexual offending in England and Wales. Ministry of Justice, Home Office \& the Office for National Statistics.

3. Rape Crisis. (2014). Rape crisis - statistics. Retrieved from http://www.rapecrisis.org.uk/Statistics2.php

4. Fisher, B. S., Cullen, F. T., \& Turner, M. G. (2001). The sexual victimization of college women. (Research Report No. NCJ 182369). USA: National Institute of Justice.

5. National Union of Students. (2010). Hidden marks. London: National Union of Students.

6. Burt, M. (1980). Cultural myths and supports for rape. Journal of Personality and Social Psychology, 38, 217-230.

7. Lonsway, K. \& Fitzgerald, L. (1994) Rape myths: In review. Psychology of Women Quarterly, 18, 133-164.

8. Franiuk, R., Seefelt, J., \& Vandello, J. (2008). Prevalence of rape myths in headlines and their effects on attitudes towards rape. Sex Roles, 58, 790-801. 
9. Edwards, K. M., Turchik, J. A., Dardis, C. M., Reynolds, N., \& Gidycz, C. A. (2011). Rape myths: History, individual and institutional-level presence and implications for change. Sex Roles, 65, 761773. doi: 10.1007/s11199-011-9943-2

10. Moor, A. (2007). When recounting traumatic memories is not enough: Treating persistent selfdevaluation associated with rape and victimblaming rape myths. Women \& Therapy, 30, (1-2) 19-33.

11. Ryan, K. M. (2011). The relationship between rape myths and sexual scripts: The social construction of rape. Sex Roles, 65, 774-782. doi: 10.1007/s11199011-0033-2

12. Das, M., Ghosh, S., Verma, R., O'Connor, B., Fewer, S., Virata, M. C., \& Miller, E. (2014). Gender attitudes and violence among urban adolescent boys in India. International Journal of Adolescence and Youth, 19(1), 99-112.

13. Glick, P., \& Fiske, S. T. (1996). The ambivalent sexism inventory: Differentiating hostile and benevolent sexism. Journal of Personality and Social Psychology, 70(3), 491512.

14. Chapleau, K. M., Oswald, D. L., \& Russell, B. L. (2007). How ambivalent sexism toward women and men support rape myth acceptance. Sex Roles, 57(1-2), 131136

15. Abrams, D., Viki, G. T., Masser, B., \& Bohner, G. (2003). Perception of a stranger and acquaintance rape: The role of benevolent and hostile sexism in victim blame and rape proclivity. Journal of Personality and Social Psychology, 84, 111-125.

16. Durán, M., Moya, M., Megías, J. L. \& Viki, G. T. (2010). Social perception of rape victims in dating and married relationships: the role of perpetrator's benevolent sexism. Sex Roles, 62, 505-519. doi:10.1007/s11199-009-9676-7

17. Sakallı-Uğurlu, N., Yalçın, Z. S., \& Glick, P. (2007). Ambivalent sexism, belief in a just world, and empathy as predictors of Turkish students' attitudes toward rape victims. Sex Roles, 57(1112), 11-12889-895. doi:10.1007/s11199-007-93132

18. Forbes, G. B., Jobe, R. L., White, K. B., Bloesch, E., \& Adams- Curtis, L. E. (2005). Perceptions of dating violence following a sexual or nonsexual betrayal of trust: Effects of gender, sexism, acceptance of rape myths, and vengeance motivation. Sex Roles, 52, 165-173.

19. Valor-Segura, I., Expósito, F., \& Moya, M. (2008). Atribución del comportamiento del agresor y consejo a la víctima en un caso de violencia doméstica [Attribution of the aggressor's behavior and advice to the victim in a case of domestic violence]. Revista de Psicología Social, 23, 171180. doi:10.1174/021347408784135896

20. Olson, J. E., Frieze, I. H., Wall, S., Zdaniuk, B., Ferligoj, A., Kogovšek, T., Pauknerová, D. (2007). Beliefs in equality for women and men as related to economic factors in central and eastern
Europe and the United States. Sex Roles, 56(5-6), 297-308.

21. Zawisza, M., Luyt, R., \& Zawadzka, A. M. (2015). Societies in transition: Are they more sexist? A comparison between polish, South African and British samples. Journal of Gender Studies, 24(1), 38-55.

22. Johnson, B. E., Kuck, D. L., \& Schander, P. R. (1997). Rape myth acceptance and sociodemographic characteristics: A multidimensional analysis. Sex Roles, 36(11-12), 693-707. doi: 10.1023/A:1025671021697

23. Aosved, A. and Long, P. (2006). Co-occurrence of rape myth acceptance, sexism, racism, homophobia, ageism, classicism, and religious intolerance. Sex Roles: A Journal of Research, 55(7), 7-8481-492.

24. Payne, D. L., Lonsway, K. A. and Fitzgerald, L. F. (1999) Rape Myth Acceptance: Exploration of Its Structure and Its Measurement Using the Illinois Rape Myth. Acceptance Scale.Journal of Research in Personality, 33 (1), 27- 68.

25. Yamawaki, N. (2007). Rape perception and the function of ambivalent sexism and gender role traditionality. Journal of Interpersonal Violence, 22(4), 4406-423.

26. Chapleau, K. M., Oswald, D. L., \& Russell, B. L. (2008). Male rape myths: the role of gender, violence, and sexism. Journal of Interpersonal Violence, 23(5), 600-615.

27. Forbes, G. B., Adams-Curtis, L. E., \& White, K. B. (2004). First- and second-generation measures of sexism, rape myths and related beliefs, and hostility toward women: Their interrelationships and association with college students' experiences with dating aggression and sexual coercion. Violence against Women, 10(3), 236-261.

28. Chapleau, K. M., \& Oswald, D. L. (2014). A system justification view of sexual violence: Legitimizing gender inequality and reduced moral outrage are connected to greater rape myth acceptance. Journal of Trauma \& Dissociation, 15(2), 2204-218.

29. Viki, G. T., \& Abrams, D. (2002). But she was unfaithful: Benevolent sexism and reactions to rape victims who violate traditional gender role expectations. Sex Roles, 47(5-6), 5-6289-293.

30. Aronowitz, T., Lambert, C. A., \& Davidoff, S. (2012). The role of rape myth acceptance in the social norms regarding sexual behavior among college students. Journal of Community Health Nursing, 29(3), 3173-182.

31. Diehl, C., Glaser, T., \& Bohner, G. (2014). Face the consequences: Learning about victim's suffering reduces sexual harassment myth acceptance and men's likelihood to sexually harass. Aggressive Behavior, 40(6), 6489-503. doi:10.1002/ab.21553

32. Hammond, E. M., Berry, M. A., \& Rodriguez, D. N. (2011). The influence of rape myth acceptance, 
sexual attitudes, and belief in a just world on attributions of responsibility in a date rape scenario. Legal and Criminological Psychology, 16(2), 2242-252.

33. Hayes, R. M., Lorenz, K., \& Bell, K. A. (2013). Victim blaming others: Rape myth acceptance and the just world belief. Feminist Criminology, 8(3), 3202-220.

34. Paul, L. A., Kehn, A., Gray, M. J., \& SalapskaGelleri, J. (2014). Perceptions of, and assistance provided to, a hypothetical rape victim: Differences between rape disclosure recipients and nonrecipients. Journal of American College Health, 62(6), 6426-433.

35. Brandt, M. J. (2011). Sexism and gender inequality across 57 societies. Psychological science, 22(11), 1413-1418.
36. Clark, M. D., \& Carroll, M. H. (2008). Acquaintance rape scripts of women and men: Similarities and differences. Sex Roles, 58(9-10), 9-10616-625.

37. Süssenbach, P., Bohner, G., \& Eyssel, F. (2012). Schematic influences of rape myth acceptance on visual information processing: An eye-tracking approach. Journal of Experimental Social Psychology, 48(3), 3660-668.

38. Glick, P., \& Fiske, S. T. (2001). An ambivalent alliance: Hostile and benevolent sexism as complementary justifications for gender inequality. American psychologist, 56(2), 109.

39. Jewkes, R. (2002). Preventing domestic violence: most women welcome inquiries, but doctors and nurses rarely ask about it. BMJ: British Medical Journal, 324(7332), 253. 